\title{
Improve national competitiveness capacity under Vietnamese law
}

\author{
Duc Chinh Duong ${ }^{1, *}$ \\ ${ }^{1}$ Vietnam National University, 144 Xuan Thuy str., Cau Giay, Hanoi, 10000 Vietnam
}

\begin{abstract}
Competition is characteristic of the market economy when the supply and demand of goods and commodity prices are the decisive factors. Competition of enterprises has a direct effect on the national competition. When enterprises develop sustainably, they will promote the development of social production, increase in social labor productivity and improve people's lives. Over the past 30 years of renovation, the competitiveness capacity of Vietnam has changed and improved gradually, but compared to the world and the ASEAN region, it remains low. Good national competition will ensure to improve the business environment, increase competitiveness, to adapt to the new production in the 4.0 industrial revolution, helping the Vietnamese economy to develop stably firmly in a competitive environment.In the framework of this article, the author focuses on the following issues: (i) Some general theoretical issues about competition and national competitiveness capacity; (ii) Some legal issues in the current competition law in 2018; (iii) Some solutions to improve national competitiveness capacity.
\end{abstract}

\section{Introduction}

National competitiveness capacity is the combination of institutions, policies and factors that determine the efficiency and productivity of a country. An efficient and productive economy is one that is capable of using and exploiting limited resources well. The essence of national competitiveness capacity is the ability to operate the economy with efficiency, at the most reasonable cost, bringing in the most prosperous and sustainable results. Thus, national competitiveness capacity has a close correlation with the business environment. Therefore, completing and ensuring the effectiveness and efficiency of the implementation of legal regulations as well as mechanisms and policies, facilitating business activities not only contribute to improving productivity and quality of enterprise operations but also promote transparent resource allocation transparently, thereby having a direct and indirect impact on the national production, contributing to improving the productivity of the economy. Therefore, good national competition will ensure to improve the business environment, increase competitiveness, to adapt to the new production in the 4.0 industrial revolution, helping the Vietnamese economy to develop stably firmly in a competitive environment.

Competition is characteristic of the market economy when the supply and demand of

${ }^{*}$ Corresponding author: duongtam.dhktqd@gmail.com 
goods and commodity prices are the decisive factors. Competition of enterprises has a direct effect on the national competition. When enterprises develop sustainably, they will promote the development of social production, increase in social labor productivity and improve people's lives. Over the past 30 years of renovation, the competitiveness capacity of Vietnam has changed and improved gradually, but compared to the world and the ASEAN region, it remains low. According to the Global Competitiveness Report, in 2015, Vietnam ranked 56 out of 140 economies, reaching 4.3 out of 7 points, increasing 12 steps compared to 2014. Up to now (2020), according to ICAEW, Vietnam is believed to be the only economy in Southeast Asia to achieve positive growth in 2020. Through analyzing indexes for the assessment of the national competitiveness, the Central Economic Committee said that it is necessary to focus on analyzing, evaluating and giving solutions to improve the business environment and improve national competitiveness capacity, such as: The group of factors on economic institutions and economic institutions enforcement (legal regulations and law enforcement in business and competition; judicial reform; corruption prevention; reform of public administration); Group of macroeconomic issues, such as: Macroeconomic environmental sustainability; the reality of total factor productivity (TFP) in Vietnam's growth model; Group of issues of accessing resources and markets, such as: developing basic resources for production and business activities of enterprises; developing of market factors and types of markets; Group of business development and startup issues and a group of issues related to security, safety as well as social factors... Thus, the national competition is a major problem in the country. In the framework of this article, the author focuses on the following issues: (i) Some general theoretical issues about competition and national competitiveness capacity; (ii) Some legal issues in the current competition law in 2018; (iii) Some solutions to improve national competitiveness capacity.

\section{Materials and research methods}

The author uses a combination of research methods, such as: Comparing jurisprudence, statistics, analysis, synthesis, interpretation, inductive method... On the basis of the methodology of dialectical materialism and historical materialism of Marxism-Leninism as well as the Party's viewpoint on enhancing national competitiveness capacity. With rich references from textbooks on competition, the competitiveness of domestic universities, articles of relevant domestic and foreign authors, online newspapers, e-newspapers from the web portal of the Government, Ministries, Departments...to clarify research issues.

\section{Research results}

\subsection{Some general theoretical issues about competition and competitiveness capacity}

At present, the trend of globalization and regionalization of the economy is taking place strongly. It presents each country with advantages, at the same time, with extreme difficulties and challenges. Vietnam is also actively integrating its economy into the region and the world. However, with the current situation of Vietnam's economy, integration problems are posing to the State and enterprises must promote their efforts to prepare well for the integration process. It is necessary to promote industrialization and modernization of the economy so that when Vietnam takes the initiative in economic integration, there will be no surprise and effective integration. With the characteristics of the transitional economy, Vietnam has risen and strongly applied the theory of competition. Competition has brought the market and social life a new, flexible, diversified, rich and glowing face, 
and at the same time raised many social problems, such as Bankruptcy, fraudulent business, unfair competition... Over the past 30 years of market economy development in Vietnam, competition is no longer new in socio-economic life and the legal sciences of Vietnam. However, in law enforcement and legislative affairs of competition, we still have too little experience. Therefore, the systematization of the theories of competition that economists, legal scientists of the market economy is a necessary and urgent duty in the current period.

Thus, it can be affirmed that: Competition is an economic rivalry between businesses with similar interests in the same market in different ways to get the most amount of customers for themselves as well as the market and market share of a market, through which more profits are obtained.

Basic characteristics of competition:

Firstly, competition is a social phenomenon that takes place between business entities. Competition only appears when there are many enterprises of different economic sectors and forms of ownership. Economics has shown that competition is the activity of business entities to compete or expand the market, requiring the existence of many enterprises in the market, then competition will become the driving force for enterprises to do better business if they belong to different economic sectors with different interests and calculations.

Secondly, in terms of form, competition is the emulation, rivalry between enterprises to resolve potential conflicts of interests between businesses and the decisive role of consumers. In business, profit is the driving force for market entry, a measure of success and the aim of enterprises. The Marxist political economy pointed out that the source of profits was the surplus value that capitalists found in the cycles of production, the moneygoods transition (1). In that cycle, customers and consumers act as representatives of the market, deciding to whom the society's surplus-value will belong. There, the profitability of each business will be proportional to their own ability to meet the needs of customers and consumers in society.

Thirdly, the purpose of enterprises participating in the competition is to compete for the market to buy or sell products. With the highest goal of profit, enterprises when participating in the market are always competing for the best opportunities to expand the market. With the help of consumers, the market picks out the winners and gives them the benefits they want. In the market, the competition only occurs between enterprises that share potential interests in input materials (competition to buy); or the output market for the product (competition to sell) of the manufacturing process. That having the same interests to compete makes enterprises become each other's competitors.

Some theoretical issues about competitiveness and national competitiveness capacity.

a. The concept of competitiveness capacity: Competitiveness capacity is to demonstrate the capabilities and advantages of business subjects over competitors in best satisfying the requirements of customers to get higher and higher profits. Competitiveness must be compared to specific competitors, specific products and commodities on the same market and at the same time.

b. Classification of competitiveness capacity: Normally, competitiveness capacity is considered at three different levels, which are: National competitiveness; enterprise competitiveness and product competitiveness. In the scope of this article, the author goes into depth research on national competitiveness capacity.

*National competitiveness capacity: National competitiveness capacity is its ability to achieve rapid and sustainable results in living standards, that is, to achieve high economic growth, and to determine changes in gross domestic product per capita over time. At the country level, competitiveness means national productivity. Competitiveness capacity depends on the productivity of using of human resources, capital resources of a country because productivity determines a sustainable standard of living expressed through wages, rate of return from capital spent, rate of return on natural resources...According to ICAEW, 
Vietnam is believed to be the only economy in Southeast Asia to achieve positive growth in 2020. The report predicts that the gross domestic product (GDP) of Southeast Asia will decrease by $4.2 \%$ by 2020 , this report also identifies an operational recovery in the fourth quarter of 2020. Specifically, economies that have well controlled epidemics, such as Thailand and Vietnam will recover stronger than countries like Indonesia and the Philippines - two countries are struggling to cope with the new wave of acute respiratory infections COVID-19 after loosening of restrictions. Indonesia's GDP in 2020 is forecasted to decrease by $2.7 \%$. The Philippines is forecasted to have the lowest GDP in 2020 in Southeast Asia, with a decline of $8.2 \%$, due to its reliance on international tourism and slow lifting of blockade orders. Meanwhile, the British magazine - The Economist gives positive reviews on the growth prospects of the Vietnamese economy in 2020. According to this magazine, due to the impact of the COVID-19 epidemic, there are very few new economies that have opportunities for growth and development. In that context, only a few new economies will still grow, maybe China, Egypt and Vietnam. Vietnam has a favorable position to soon get out of the "COVID-19 economic trap" by two important factors, namely:

- By creating enough fiscal space to implement ambitious fiscal stimulus, the Government of Vietnam can increase both aggregate demand in the short term and aggregate supply in the long term by spending more and better.

- At the forefront of the fight against the COVID-19 epidemic, Vietnam has increased its mark on the world economy, thereby attracting foreign businesses seeking to diversify operations and reduce risks related to other shocks in the future. The Global Research Report for the second quarter of 2020 of Standard Chartered Bank (UK) has just predicted that Vietnam's economy will grow by $3 \%$ in 2020 amid a weakening global market demand.

In the book "Global Productivity: Trends, Motivations, and Policy", the World Bank has used an algorithm to sort groups of countries based on the productivity of 97 economies since 2000. Accordingly, the 5th group is the most successful group, covering all developed economies as well as 16 current new emerging markets, such as China, India, Malaysia, Thailand and Vietnam. In recent years, the Vietnamese government has had many policies and measures to stimulate the economy, support enterprises, and at the same time attract the movement of foreign capital in the region. Economic and trade international cooperation, which is currently struggling with epidemic control measures, could be restarted in 2021 when entry restrictions were removed. In general, newspapers and international financial institutions all stated that Vietnam's economy would soon return to growth, thereby gradually asserting Vietnam's position in the global economy of the post-COVID-19 period.

\subsection{Some legal issues in the competition law of Vietnam}

Competition Law was passed on June 12, 2018, by the 14th National Assembly of the Socialist Republic of Vietnam at the 5th session. The law provides competition restriction behavior, economic concentration, causing or likely causing competition restraint impacts on the Vietnamese market; unfair competition practices; competition proceedings; handle violations of competition laws; State management over competition are the main contents of the Competition Law in Vietnam. According to this Law, subjects of application are business organizations and individuals (hereinafter collectively referred to as enterprises), including enterprises that manufacture and supply public products and services, and enterprises operating in state-monopolized sectors and fields, public non-business units and foreign enterprises operating in Vietnam, industry associations operating in Vietnam, and related domestic and foreign agencies, organizations and individuals. 
- According to Article 5 of the law, the rights and principles of competition in business are: Enterprises have the right to free competition in accordance with the law. The State guarantees the legal right to compete in business. Competition activities are conducted according to the principles of honesty, equity and fairness, not infringing the interests of the State, public interests, legal rights and interests of enterprises and consumers. Also according to Article 6 of the Law, the State's policies on competition are: Create and maintain a fair, equity, and transparency competition environment; promote competition, ensure the right to freedom of competition in business in accordance with the law; enhance market access capacity, improve economic efficiency, social welfare and protect consumers' interests; create conditions for the society and consumers to participate in the monitoring process of the implementation of competition laws. Also according to Article 8 of this Law, the prohibited acts related to the competition are: When state agencies commit acts that obstruct competition in the market (such as: force, request, recommend enterprises, agencies, organizations and individuals to perform or not perform the production, purchase and sale of goods, supply and use of specific services or buy, sell goods, supply, use services with specific enterprises), excepting for goods and services in the fields of state monopoly, discriminate among enterprises; force, request and recommend industry associations, other socio-professional organizations or enterprises to link together to limit competition in the market; abuse positions and powers to illegally intervene in competition activities or organizations, individuals providing information, advocating, calling, forcing or organizations which are let enterprises to conduct acts of competition restriction, unfair competition are strictly prohibited.

- Regarding competitive market: Relevant market is defined on the basis of the relevant product market and relevant geographic market. In particular, the relevant product market is the market of interchangeable goods and services in terms of characteristics, use purposes and prices, while the relevant geographical market is a specific geographical area, in which there are goods or services provided that are interchangeable with similar competitive conditions and which differ significantly from neighboring geographic areas.

- Regarding the competition restriction agreement, according to Article 11 of the Law, it is an agreement that directly or indirectly fixes prices of goods and services; agreement on customer division, distribution of markets, supply of goods, provision of services; Agreements on limiting or controlling the quantity or volume of production, purchase and sale of goods or provision of services; agree to let one party or parties of the agreement to win bids when participating in tenders for the provision of goods or services; agreement to prevent, restrain, prevent other enterprises from participating in the market or developing business; agreement to remove from the market enterprises that are not parties to the agreement; agreement to restrain technical and technological development, and limit investment; agreement to impose or fix conditions for signing contracts to buy, sell goods or provide services to another enterprise or to force another enterprise to accept obligations not directly related to the contract objects...

- Unfair competition is prohibited in the following cases: (according to Article 45 of the law), it is the infringement of confidential information in business in the forms, such as: Access, collect confidential information in business by opposing the confidentiality measures of the person who owns it; disclose and use confidential information in business without the permission of the owner of such information; force customers, business partners of other enterprise by threatening or forcing them not to transact or stop transactions with that enterprise; provide dishonest information about another enterprise by directly or indirectly giving dishonest information about the enterprise, which adversely affects its reputation, financial status or business operations of the enterprise; disrupt business activities of other enterprises by directly or indirectly obstructing or interrupting the lawful business activities of that enterprise; illegally solicit customers by forms, such as: Give 
false or misleading information to customers about the enterprise or goods, services, promotions, transaction conditions related to goods or services that the enterprise provides to attract customers of other enterprises, compare their own goods or services with those of another enterprise but cannot prove the content; sell goods or provide services below the overall cost price leading to or possibly leading to the elimination of other enterprises doing business with that kind of goods or services are all considered unfair competition practices.

- Regarding competition proceedings: According to Articles 54,55,56, 57 of the law, competition proceeding agencies, participants in competition proceedings, within the scope of their responsibility, rights and obligations, must keep secrets of information relating to competition cases and business secrets of enterprises in accordance with the law; respect for legitimate rights and interests of enterprises, organizations and individuals involved in competition legal proceedings. Evidence (readable, audible, visible documents, electronic data; exhibits; testimonies and presentations of witnesses; testimonies, presentations and explanations of complainants and defendant or related investigation or individuals; assessment conclusions...) to perform competition legal proceedings is real, used as a basis for determining whether or not there is a violation of the law on competition.

- Regarding the competition proceeding agency, according to Article 58 of the Law, the competition proceeding agency includes: The National Competition Commission; Council on the settlement of competition restriction; Council on complaint settlement of decisions on handling competition cases; Investigation agency on competition cases.

- People who conduct competition legal proceedings include: President of the National Competition Commission; Chairman of Council on the settlement of competition restriction; members of Council on the settlement of competition restriction; members of Council on complaint settlement of decisions on handling competition cases; Head of the Investigation agency on competition cases; investigator of competition cases; secretary of the hearing. - Regarding participants in competition legal proceedings under Article 66 of the law, including: Complainant; the complained party; investigated party; persons with related interests and obligations; defense counsels of legitimate rights and interests of the complainant, the complained party, the investigated party, persons with related interests and obligations; witnesses; examiners.

- Regarding the settlement of a complaint of decisions on handling competition cases, according to Article 96, within 30 days from the date of receiving the decision on handling a competition case, the organization or individual does not agree with a part or the entire content of the decision on handling the competition case has the right to complain to the President of the National Competition Commission by a complaint of the decision on handling the competition case together with additional information and evidence (if any) to prove that claim is valid and legal.

- Regarding the handling of competition law violations, according to Article 110 of the Law, organizations and individuals that commit violations of the competition law shall, depending on the nature and severity of their violations, be disciplined, administratively sanctioned or examined for penal liability, if causing damage to the interests of the State or the legitimate rights and interests of organizations and individuals, they must compensate for the damage according to the provisions of law. For each act of violating the law on competition, the violating organization or individual shall be subject to one of the sanctions such as: Warning or a fine or revocation of enterprise registration certificate, deprivation of the right to use licenses or practice certificates; confiscation of material evidence and means used in violation of competition law; confiscation of the profits earned from the commission of violations. Also according to Article 115 of the Law, the implementation of the decision on complaint settlement or decision on handling competition cases is done after 15 days after the decision on complaint settlement or decision on handling competition cases takes legal effect but the party that must execute fails to voluntarily execute or does 
not initiate a lawsuit at court as prescribed in Article 103 of this Law, the enforcement party, the National Competition Commission has the right to request a competent state agency to organize the implementation of the decision.

\subsection{Solutions to improve national competitiveness capacity}

In 2019, most of the general indexes of Vietnam have been improved. National competitiveness capacity increased 3.5 points and 10 steps with $8 / 12$ increased pillars and increased many steps. The Innovation index increased 3 steps with $6 / 7$ groups of increased pillars. The business environment improved by 1.2 points. Also in 2020, Vietnam strives to do business environment according to the EoDB (World Bank) ranking of 10 steps; competitiveness according to GCI 4.0 rating (of the World Economic Forum (WEF)) by 5 steps; innovation according to GII rating (of the World Intellectual Property Organization (WIPO)) by 3, 4 steps; E-government (of the United Nations - UN) from 10 to 15 steps. To maintain and improve national competitiveness ranking indexes of Vietnam compared to other countries in the region and around the world, Vietnam needs to synchronously implement the following solutions:

Firstly: Continue to improve the ranking of business environment indexes:

With tasks and solutions to further improve the point and ranking of business environment indexes, in which, on Business startup, the Ministry of Finance in the first quarter of 2020 proposes to amend the Decree No. 139/2016/ND-CP dated October 4, 2016 of the Government regulating license fees towards delaying the deadline for declaration and payment of license fees by January 30 of the following year; supervise the implementation of regulations on procedures for printing / self-printing of invoices and a notice of issuance within 04 days as prescribed; for procedures to buy invoices, it must ensure to be solved within the same day; promote the use of electronic invoices according to the Decree No. 119/2018/ND-CP dated September 12, 2018 of the Government stipulating on electronic invoices when selling goods and providing services. The Ministry of Labor, Invalids and Social Affairs shall chair and coordinate with the Ministry of Planning and Investment in studying and building an online labor declaration information system connected to the national information system of enterprise registration that shall be completed in the fourth quarter of 2020. The Ministry of Planning and Investment continues to complete the draft Law on Enterprises (amended) in the direction of abolishing or simplifying unnecessary procedures, in order to shorten the time and cost of market entry. Regarding construction licensing, ministries and provincial-level People's Committees continue to strictly implement the Directive No. 08/CT-TTg dated March 13, 2018 of the Prime Minister on enhancing the implementation of measures to shorten the construction permit period. Regarding access to credit, the State Bank of Vietnam continues to effectively implement measures to maintain the credit information depth index; direct credit institutions to create favorable conditions for people and enterprises to access credit fairly and transparently. In the fourth quarter of 2020, the Ministry of Justice shall complete researches and propose amendments and supplements to the Decree guiding provisions of the Civil Code 2015 on secured transactions, in which completion of regulations on secured transaction registration, the order of payment priority. Regarding property registration, the Ministry of Natural Resources and Environment shall chair, and coordinate with the Ministry of Finance and concerned agencies in proposing and guiding localities to implement necessary solutions to shorten the implementation time of procedures for granting certificates of ownership of works attached to the land, procedures for transfer of house ownership, registration of land use rights are ensured in accordance with current regulations.

Secondly: Reform regulations on business conditions

Substantial reform of regulations on business conditions. Specifically, ministries and 
ministerial-level agencies update, publish and publicize administrative procedures related to the issuance of simplified business eligibility certificates in 2018 and 2019; publicized comparison tables of business conditions before and after abolition, simplification. With administrative procedures related to the issuance of business eligibility certificates simplified from 2020 onwards, it will study and propose amendments to relevant laws to abolish and simplify the business conditions are specified in specialized laws according to the approved plan. The Ministry of Justice enhances the quality of appraisal and promulgation of business investment conditions in draft Laws and Decrees to ensure compliance with the Law on Investment and Decrees on business investment conditions. Presidents of the People's Committees of provinces shall direct the correct and full implementation of the simplified business conditions; do not set additional business conditions in any form. The Ministry of Planning and Investment shall chair, and coordinate with the Government Office in monitoring and evaluating the situation and results of the comprehensive reform of regulations on business conditions in ministries, branches and localities; report to the Prime Minister before December 20, 2020.

Thirdly: Substantially reduce $50 \%$ of the items on the list of specialized inspection items

Continue to implement comprehensive reforms of management, specialized inspection and connection of the National One-Stop Shop (OSS) Mechanism, the ASEAN One-Stop Shop Mechanism. In particular, the Government requires ministries and ministerial-level agencies to fully implement the reforms in specialized management and inspection by the end of 2020, including: Applying risk management based on assessment and analysis of the compliance level of enterprises and the level and scale of risks of goods; shifted strongly from mainly inspecting at the customs clearance stage to mainly supervising in the domestic market; publish and publicize the list of goods subject to specialized inspection with HS code (the code used to classify exports and imports worldwide) at a detailed level, how to manage especially export and import respectively and the costs that enterprises have to pay; the publicity must be appropriate and accessible; apply online public service at the level 4. Complete the review and substantially cut $50 \%$ of the items on the list of goods subject to specialized inspection (the List of goods subject to specialized management and inspection at the time of promulgating the Resolution No. 19/2018/NQ- CP dated May 15, 2018). Fully publish and publicize on the website of ministries of specialized management on lists with corresponding HS codes, together with a comparison table of the list of specialized management and inspection items before and after cutting. The Ministry of Finance sets up and submits to the Government for approval the master project on building and developing an information technology system to serve the implementation of the National One-Stop Shop (OSS) Mechanism, the ASEAN One-Stop Shop Mechanism according to the orientation of centralized handling; strongly reforming customs procedures towards electronicization, towards electronic customs, in accordance with international standards. In addition, the Ministry studies and proposes solutions to immediately solve problems in the application of tax on excess raw materials and supplies from export production and processing; assume the prime responsibility for monitoring the situation, assessing the results of the implementation of specialized management and inspection reforms; assesses the level of changes and impacts on import and export enterprises; reports to the Prime Minister before December 20, 2020. The Ministry of Agriculture and Rural Development applies the principles of risk management, prioritization, mutual recognition in specialized management and inspection of seafood export and import activities; guides and distinguishes between quarantine and food safety inspection; gives specific and clear instructions on how to check (especially sensory testing) ensuring consistent implementation, avoiding incurring costs for enterprises; chairs, and coordinates with the Ministry of Finance in reviewing and amending the Circular No. 285/2016/TT-BTC on the calculation of fees and charges in veterinary activities to reduce unreasonable costs for 
enterprises.

Fourthly: Promote non-cash payment:

Non-cash payment is a popular method used by countries in the region and around the world. In Vietnam, the Government requires Ministers and Heads of ministerial-level agencies to direct the provision of at least $30 \%$ of online public services under their jurisdiction at the level 4; allow people and enterprises to make non-cash payments by many different means; integrate into the national public service portal according to the roadmap; step up the mode of receiving documents and returning the results of settlement of administrative procedures via public postal services. The Ministry of Information and Communications accelerates the licensing progress for the $2.6 \mathrm{GHz}$ band to deploy $4 \mathrm{G}$ networks for telecommunications enterprises in accordance with the law. The State Bank of Vietnam shall chair, and coordinate with the Ministry of Justice and relevant agencies in studying and proposing the Prime Minister to issue a Decision on pilot use of telecommunications accounts to pay for services with small value (Mobile-Money), pilot new payment service models in the absence of legal regulations to promptly ensure management, especially for cross-border payment operations. Synthesize and evaluate the results of the implementation of the Project on the development of non-cash payments in Vietnam for the period 2016 - 2020 issued under the Decision No. 2545/QD-TTg dated December 30, 2016 of the Prime Minister; propose measures to promote non-cash payment in the coming time. The Ministry of Education and Training directs all schools to coordinate with credit institutions and intermediaries in paying tuition fees by non-cash payment method. The Ministry of Labor, Invalids and Social Affairs and Vietnam Social Insurance shall develop and promulgate according to its competence guidelines, standards, and roadmap for standardization of data on pensioners and social insurance recipients, social welfare regimes to connect and share information with credit institutions, payment intermediaries in order to pay social welfare, pensions and social insurance benefits via banks. The Ministry of Health directs hospitals to coordinate with credit institutions and payment intermediaries in collecting hospital fees by the non-cash mode; strives to achieve the target determined in the Decision No. 241/QD-TTg dated February 23, 2018 of the Prime Minister which is that $50 \%$ of hospitals in big cities accept payment of hospital fees via banks...

\section{Conclusion}

The above analysis shows that, although the Vietnamese economy has made many efforts, some basic indicators in the indexes for ranking the competitiveness capacity are slow to improve and have a modest ranking position compared to many countries in the region. Thus, the competitiveness of enterprises is one of the determining factors of national competitiveness capacity. The Government's efforts to improve the business environment are aimed at creating a favorable environment for enterprises to promote creativity and innovation in order to be competitive in domestic and international markets. Therefore, enhancing national competitiveness requires not only the determination of the Government but also the efforts of enterprises themselves. The competition will create pressure for enterprises to constantly explore, innovate, improve production methods and organize business management, innovate technology, apply for scientific and technical advances, and develop new products, increase labor productivity, lower product costs, thereby contributing to improving social labor, ensuring people's lives and stabilizing social security and order. 


\section{References}

1. Anh Dang, S. Goldstein, J. McNally, The International Migration Review 31(2), 312 37 (1997) doi:10.2307/2547222

2. V. Thanh, Journal of Southeast Asian Economies 32(1), 106-124 (2015) http://www.jstor.org/stable/44132180

3. Nguyen Manh Hung, Southeast Asian Affairs 2004, 297-311 (2004) http://www.jstor.org/stable/27913267

4. B. Womack, Government and Opposition 27(2), 177-189 (1992) http://www.jstor.org/stable/44483713

5. L.E. Grinter, Asian Affairs 33(3), 151-65 (2006) http://www.jstor.org/stable/30173023

6. V. Thanh, Journal of Southeast Asian Economies 32(2), 275-288 (2015) http://www.jstor.org/stable/44132196

7. Le Anh Tu Packard, S.S. Thurman, ASEAN Economic Bulletin 13(2), 241-64 (1996) http://www.jstor.org/stable/25773430

8. M. Piei, N. Khalifah, ASEAN Economic Bulletin 13(2), 200-211 (1996) http://www.jstor.org/stable/25773427 